\title{
Interrogational Fairness under the European Convention on Human Rights
}

Wei Wu

\begin{abstract}
[Abstract]
This article examines the contribution of the European Court of Human Rights to the development of interrogational fairness at the pretrial phase in modern European criminal proceedings. Although the Convention contains no explicit reference to the right to remain silent and the privilege against selfincrimination, the Court, drawing its rationale from Article 6 of the Convention, has been steadily developing its distinctive vision of these immunities in an attempt to create a doctrine that sets a limit below which contracting parties could not allow their legal systems to fall, while also acting in accordance with the established procedures within the civil and common law traditions of its Contracting States. It is shown that the Court's jurisprudence has produced a carefully balanced doctrinal framework that respects the individual's choice to remain silent without creating absolute immunities. Simultaneously the Court's approach in defining defence rights not only reflects what is says about the universality of the right to remain silent but also gives plenty of scope for diverse applications in different institutional and cultural settings.
\end{abstract}

\section{Introduction}

Police interrogation during the investigation phase is recognized as an accepted and essential aspect of law enforcement in all legal systems. Nevertheless, at the same time, police questioning as an aid to law enforcement has been the focus of intense interest and debate continuously. Specifically, the recognition of the value of confessions has been accompanied by concerns over the factual accuracy of statements and the fairness of the manner in which they are obtained (Ma, 2000).

On the European continent, in both common and civil law traditions, the judge at trial must decide what evidence can and cannot be used for a conviction. The incriminating statements and silence made during the course of police interrogation and used as evidence against the suspect is one of the issues that trial judges or juries consider on a routine basis. It is here that we encounter one of the most often repeated generalizations in comparative discussion of the 
law of confession. It is said that common law systems are mainly concerned with the issue of admissibility and tend to emphasize the respect given to a suspect's autonomous right to decide whether and how to participate in defending herself. Civil law systems, on the other hand, emphasize a more 'social' approach which obliges states to take positive action to protect the rights of the suspect and to take account of all statements that are logically relevant whether of an exculpatory or inculpatory nature (Damaska, 1973; Jackson, 2009b). Certainly, no system in reality is entirely adversarial or entirely inquisitorial, but in most systems the values of one or the other model appear to predominate (Sanders and Young, 2007).

However, in recent years, some commentators have detected a slow, gradual 'convergence' in the interrogation procedure of common and civil law systems in Europe (Bradley, 1999; Van Kessel, 2002). As knowledge of, and familiarity with, other systems increases, each legal system is tempted to seek new solutions to deal with similar problems drawing from the experience of others. Therefore, inquisitorial procedures are increasingly influenced by the necessity of fairness in police interrogation at the pretrial stage, whereas there are some indications that adversarial questioning is beginning to avail itself of the instruments of truth-finding. In addition to these internal pressures, there have been external pressures on states to adopt common procedural standards in police questioning. The thrust toward 'convergence' would seem to be at its strongest within Europe where supranational institutions, such as the Council of Europe and the European Union ${ }^{1}$, provide a vehicle for strengthening cooperation within a framework of common procedural rights and guarantees laid down by the European Convention on Human Rights and, more recently, the EU Charter of Rights (Cape, Namoradze, Smith, and Spronken, 2010). Notably, although the European Court of Human Rights has neither the jurisdiction to strike down national laws, nor have the authority to order a state to change its legislation, it is estimated that, taken together, both the text of the Convention and the jurisprudence of the Court have inspired numerous national, constitutional, and other court decisions. The European Court of Human Rights has also been the inspiration for legislative changes (Lahti, 1999; Jackson, 2005). Moreover, it has been the hope of European human rights law observers that the Court, through its Jurisprudence in completing and enriching the often vague text of the

\footnotetext{
${ }^{1}$ Article $82 \S 2$ of the Lisbon Treaty provides for the establishment of minimum rules in respect of, inter alia, the rights of individuals in criminal procedure. Further, on 1 July, 2009, the Swedish Presidency presented a Roadmap for Strengthening Procedural Rights of Suspected or Accused Persons in Criminal Proceedings. The Roadmap was incorporated into the Stockholm Programme for the period 2010-2014, which was adopted by the European Council on 10/11 December, 2009. The Roadmap, which provides for a step-by-step approach, identifies six areas that future EU work should focus on. Specifically, Measure C of the Roadmap, which is mainly concerned with the right to a legal counsel at the earliest appropriate stage of criminal proceedings, is due to be legislated in 2011.
} 
Convention, may exert a harmonizing influence on the criminal justice practices in the Contracting States (Ma, 2000; Bárd, 2006).

This article explores the jurisprudence on the right to remain silent and the privilege against self-incrimination of the Court, which has been attempting to fashion common standards of interrogation fairness across the common law and civil law systems of criminal procedure in Europe for a number of years. Although the Convention contains no explicit reference to the above right and the privilege, the Court, drawing its rationale from Article 6 of the Convention, has been steadily producing a carefully balanced doctrinal framework that respects the individual's choice to remain silent without creating absolute immunities. It is shown that the Court's approach in defining defence rights not only reflects the universal rationale of the right to remain silent but also gives plenty of scope for diverse applications in different institutional and cultural settings.

This article is in three parts. First, we will identify the features and limitations of the traditional adversarial-inquisitorial dichotomy. Second, we will trace the Court's recent jurisprudence on the right to remain silent and the privilege against self-incrimination with the object of showing how the Court has interpreted these immunities to develop its own distinctive version, thus throwing some light upon the practical value of the guarantee provided therein. The last part concludes.

\section{Background}

Before we come to the jurisprudence of the European Court of Human Rights, we will first identify the features and limitations of the traditional adversarial-inquisitorial dichotomy.

\subsection{The Adversarial and Inquisitorial Dichotomy}

Enforcing the criminal law is crucial to every society, but the pursuit of the ultimate social goals of criminal justice must be qualified by the goal of avoiding miscarriages of justice: the guilty should be punished and the innocent left alone (Sanders, Young, and Burton, 2010). Based on different ways in approaching a rational fact-finding process, the criminal justice system has been classically divided as being either adversarial or inquisitorial (Jorg, Field, and Brants, 1995). It is noted that the two systems differ in their fundamental assumptions as to the best way of arriving at "the truth".

The adversarial system, in theory, promotes truth-finding through the partisan clash of opposing viewpoints in which each side pursues its narrow self-interest (Jorg et al 1995; Leo, 2008). This approach draws on the system's 
historic distrust of state power. It reflects the classic liberal idea that state power must be checked to prevent an unjust or corrupt structure coming into being that would regularly risk the wrongful convictions of the innocent (Sanders, Young, and Burton, 2010; Leo, 2008). Thus, to hold state agents accountable at each stage of the criminal process, the suspect is endowed with a number of procedural presumptions and privileges even as the prosecution is saddled with procedural burdens, holding it to a complex web of rules of evidence (Jorg et al. 1995; Jackson, 2009b). Perhaps most importantly, the suspects are represented by attorneys whose obligation, however, is not to pursue truth itself but to zealously advocate the client's interest. In police questioning, this means that the attorney may prevent the introduction of highly probative evidence, for example, by advising the client not to speak, testify or cooperate, minimizing the importance of unfavourable facts, and trying to construe inferences from ambiguous evidence in the client's favour (Sanders, Young and Burton, 2010). By emphasizing the pursuit of self-interest and delegating to the parties the control of gathering and presenting evidence, the adversarial system is supposed to motivate the parties to assiduously discover facts. In principle at least, there is a strict demarcation between the investigative and trial stage in adversarial systems and the determination of guilt is reserved for the trial. The most traditional assumption in the adversarial theory is that real equality of parties and the oral contest involved in courtroom procedure will lead to truth emerging. The adversarial clash of partisan perspectives is supposed to leave the judge in the most informed position to adjudicate between disputed claims (Leo, 2008).

An inquisitorial system, by contrast, assumes that the state can be largely trusted to conduct a neutral investigation into the truth and the truth can be, and must be, discovered in an investigative procedure (Jorg et al. 1995; Sanders, Young, and Burton, 2010). Because it may be in the interests of parties to conceal the evidence, it is assumed that the legal professionals are best equipped to carry out such investigations. Based on the assumption that professional investigators employed by the state can do the criminal inquiry in a detached and impartial manner, the need for procedural safeguards such as a strict separation of investigative and adjudicative powers, rules of evidence, and defence lawyers is seen as much diminished. Public interest, rather than self-interest, is the key purpose here. This means, in contrast to lawyers in an adversarial system where a counsel may 'terminate' police interrogation by advising a client to answer no further questions, the defence lawyer's role within inquisitorial procedures serves to demonstrate that the investigative officials adhere to the rules rather than 'end' the police questioning (Hodgson, 2006). In principle, therefore, it is possible for suspects to be subjected to police interrogation without access to legal advice in this procedure (Sanders and Young, 2010). Importantly, the legitimacy of the inquisitorial procedure requires an inordinate amount of faith in the integrity of the state and its capacity to pursue truth unprompted by partisan pressures of individual self-interest and untrammelled by equality of 
arms (Jorg et al. 1995, 43). Consequently, in the inquisitorial approach, the line between the investigative and trial stage is less clear. From a functional point of view, although the judges in an inquisitorial court actively engage in discovering 'the truth', they are adjudicative rather than legislative (Jorg et al. 1995, 44).

One difference between the adversarial and inquisitorial approaches lies in their degree of success in discovering the truth. In Jeremy Bentham's view, the passiveness of the suspect in the adversarial questioning, in theory at least, had the inevitable effect of excluding the suspect's confessions (Helmholz, 1997, 3). As Damaska (1973: 587) observes, "The Anglo-American adversary system's commitment to values rather than the pursuit of truth has caused it to erect higher evidentiary barriers than its continental non-adversary counterpart." Notably, this does not mean that its factual findings are ipso facto more reliable. Higher barrier to convictions not only decreases the chances of an innocent person being convicted but also increases the chances of the guilty escaping punishment (Alschuler, 1997). Similarly, inquisitorial procedure committing to the discovery of truth is not better equipped to achieve precision in its fact finding. Truth may be loved unwisely or too much. If permanently hidden and therefore unchallenged, the state's abilities to interrogate the suspect and to discover the truth are equally dangerous. An example that presents the issue is the demanding standard of proof-sufficiency in medieval law, designed to decrease false convictions, which led to the use of torture in criminal investigations, a practice that undoubtedly increased false convictions (Langbein, 2004). Apart from this extreme example, although the accused in a democratic context should not be compelled to incriminate himself or herself, all too often, because of strong desires among police officers not to release a suspect until the truth as perceived by the police has been ascertained, the supposed safeguard against aggressive questioning offered by judicial control of the interrogation process becomes a chimera. Surely, information extracted under improper physical or psychological pressures comes with no guarantee of reliability (Jackson, 2009a).

Which of the two rival systems is better adapted to fact-finding precision has been the subject of great dispute at least since the nineteenth century. Even if one of the two systems is found to be better adapted to the discovery of truth, this will not be decisive. In the dialectics of the criminal process, concern for individual rights often sets limits to the pursuit of truth and at odds with the truth-finding considerations. According to Damaska (1973), the relation between fact-finding precision and fairness in criminal process is a zero-sum game, "for it often happens that what is gained on one front is lost on another (p. 589)." Therefore, no opinion on whether one type of procedure is superior to the other both in terms of its fact-finding precision and in terms of its fairness can be voiced. 


\subsection{Legal System in Practice}

Here we must emphasize that the classical models of adversarial and inquisitorial legal systems discussed above are theoretical ones, describing ideal types and not necessarily the functioning of the system in practice. No system in reality can correspond exactly with either model, but in most systems the values of one or the other model appear to predominate (Sanders and Young, 2007). The adversarial system is generally adopted in common law countries, such as in the England, Unites States, Canada, and Australia. Civil law countries in continental Europe such as France, Germany, and Netherlands are regarded as typical examples of inquisitorial system.

In recent years, national legal systems are attempting to seek 'foreign' solutions to similar problems in the criminal justice system. Therefore, in the field of the law of confession, changes are occurring in both systems, in the composition of the mixture between concerns over the factual accuracy of statements and the fairness of the manner in which they are obtained, and these are reflected in piecemeal changes in the organization of criminal procedure. To take two examples, despite the traditional emphasis in the inquisitorial system on the importance of truth-finding, continental European countries, however, has seen a growth in administering warnings to suspects about their right to remain silent prior to interrogation and the use of an exclusionary rule to ensure the police compliance with the warning requirement ${ }^{2}(\mathrm{Ma}, 2007)$. A countertendency in common law jurisdictions, away from an emphasis on respect for autonomy, however, is seen in the shift from giving more procedural safeguards in police questioning. The modification of British law in 1994 that curtails the right to silence and permits the courts to draw adverse inferences from a suspect's failure to answer police questions ${ }^{3}$ is a clear example of crime control

\footnotetext{
${ }^{2}$ Notably, forty-five years ago, when the U.S. Supreme Court in Miranda v. Arizona (1966) held that the Fifth Amendment privilege against self-incrimination applied to the pretrial interrogation of suspects in custody, few European countries required the police to issue preinterrogation warnings. Except for coerced confessions, it was also rare for European courts to exclude evidence for police failure to follow procedure rules (Ma, 2007, 6). The U.S. Court then seemed to lead the way in expanding the procedural safeguards for suspects subject to police inquiry. Nevertheless, in the post-Miranda cases, to accommodate the conflicting interests between law enforcement and individual interests in police interrogation cases, the U.S. Court has carved various exceptions out of Miranda exclusion policy, for instance, the public security exception, which permits the police to interrogate a suspect without the Miranda warning if there is evidence indicating that immediate interrogation is necessary for some urgent public need (Ma, 2007; Roth, 2008).

${ }^{3}$ According to The Police and Criminal Evidence Act 1984 (PACE 1984), silence during the police questioning should not be capable of being the subject of adverse comment by both the judge and the prosecution. In particular, the judge was not permitted to suggest to the jury that silence or a refusal to answer questions is in any way evidence of guilt (Zander,
} 
concerns (O'Reilly, 1997). It is clear that inquisitorial procedure is increasingly influenced by the necessity of fairness in police questioning at the pretrial stage, even as there are some indications that adversarial interrogation is beginning to avail itself of the instruments of truth-finding.

These developments would appear to suggest gradual convergence (Bradley, 1999; Van Kessel, 2002). The idea mixture, of course, is optimal truth-finding and fundamental fairness. Undoubtedly, truth-finding and fairness are the distinctive aims of criminal justice and the legitimacy of each legal system depends on its ability to do both. However, recent comparative scholarship has pointed to counter-influences at work that are actually moving the systems further away from each other. On the one hand, legal transplants may not have the effects that are intended. Because of institutional and cultural resistance within the receiving system, attempts to import 'foreign' solutions often lead to practices being 'translated' in a different way and this can lead to fragmentation and divergence rather than convergence within the systems concerned (Langer, 2004: 3-4). This suggests that we must not lose sight of the risk involved in adopting strategies and safeguards from each other's procedural styles. For interrogation safeguards to be adequate and effective, each system depends on its own historically developed institutions and the faith that different societies place in them. On the other hand, it is at the time when a state exercises its law enforcement authorities that the substantive individual rights are most likely to clash with the state's interest in seeking the most effective means of crime control (Ma, 2000; Summers, 2007). Hence, as Jorg et al. (1995: 53) pointed out, "If there are distinctive values supporting both truth-finding and fairness of procedure, minimum standards for the pursuit of each must be established as explicit objectives."

It is in this field of criminal procedural safeguards in police questioning, in the matter of forcing the state to accept full responsibility for ensuring that their own systems produce optimal results, that the jurisprudence of the European Court of Human Rights has the greatest role to play. In the next section, we will trace the Court's recent jurisprudence on the right to remain silent and the privilege against self-incrimination with the objective of showing how the Court has interpreted these immunities to develop its own distinctive version thus throwing some light upon the practical value of the guarantee provided therein.

1990, 144). However, the modification was made by the Criminal Justice and Public Order Act 1994 (CJPOA). 


\section{The Approach of the Court toward Interrogation Fairness}

In this section, we will expose readers to the Court's jurisprudence on the right to remain silent and the privilege against self-incrimination and their implications for the development of interrogation standards in the Contracting States. To help readers gain a better perspective of the implications of Court decisions, this section will start by providing a brief introduction on the history and status of the Court.

\subsection{The Rights to a Fair Police Interrogation}

In the aftermath of the World War II, to prevent the types of atrocities that took place in Europe in the first half of the twentieth century, the international community sought to express universal principles regarding state behaviour toward individuals. The United Nations Universal Declaration of Human Rights 1948 was the platform from which the principles in the language of "human rights" were first propounded (Guild, 2004). As the decades have progressed, human rights have moved on from their initial 1948 source as they have become codified in a series of international human rights treaties, notably the European Convention on Human Rights adopted by the European Council in 1950. The Convention represents a major effort by its Contracting States, now forty-seven in number, to establish a common legal standard for the protection of individual rights and freedom (Berger, 2006).

The European Convention is a unique supranational document of protection of human rights. With it were set up the two supervisory and enforcement organs, the European Commission of Human Rights ${ }^{4}$ and the European Court of Human Rights, to ensure the observance of the obligations that states assume under the Convention (Merrills, 1988). Specifically, the European Court interprets and applies the Convention when making decisions in individual cases. European citizens who have exhausted all approaches for remedies before their domestic courts may lodge a complaint with the Court claiming that one of their rights protected by the Convention was violated. However, acting neither as a European constitutional Court nor as a European Court of Appeal, the Court does not have the authority to strike down national laws nor does the Court consider that it can order a Contracting State to change its legislation. Therefore, as a matter of principle, the Court's competence has been restricted to

\footnotetext{
${ }^{4}$ The Commission was abolished in 1998 under Protocol NO. 11. The Court now performs both the initial screening function, which used to be performed by the Commission, and the function of final adjudication. Nevertheless, reports that the Commission prepared during its existence are still an important source of information as to the interpretation of the Convention (Herrmann, 2008).
} 
declaring a breach of the Convention and awarding compensation to the applicant without repealing domestic legislation or quashing judicial decisions in question (Herrmann, 2007).

This 'modest' approach adopted by the Court is also for the sake of respecting state sovereignty. The Convention was adopted with the consent of the member states of the Council of Europe and the Court's operation presupposes the preservation of that consensus (Bárd, 2006, 39). The Court was aware of the Contracting States' sovereignty concerns and the Court's own 'democracy deficit'. Therefore, as a general rule, the Court has avoided directly interfering with national law. Nevertheless, as Ma (2000: 56) noted, "most states do choose to change national laws that are questioned by the Court". It is true that the Court can hardly be said to have acted as a truly independent European 'Supreme' Court because its judgments are declaratory rather than prescriptive. But this distinction has become blurred as the jurisprudence of the Court has come to complete and enrich the often vague text of the Convention and in this manner arrive at a set of norms that seems increasingly to be that of a true supranational legal order (Jackson, 2005; Bárd, 2006).

In practice, the parts of the Convention most commonly invoked in applications made to Strasbourg authorities have been those in Article 6 on ensuring the right of fair proceedings in determining criminal liabilities (Harris, 1970; Brems, 2005). Specifically, the primary objective of Article 6 is to guarantee the right to a fair trial, which is a recognizable feature of every significant international Convention or Treaty proclaiming an allegiance to democracy, the rule of law and protecting human rights (Toney, 2001; Summers, 2007: 97). Identifying only a limited number of particularized standards within the broader fair hearing guarantees, Article 6 broadly protects individual rights in criminal proceedings (Jackson, 2005; Berger, 2006). Taken at face value, in the criminal context, the specific rights incorporated in Article 6 appear to only apply to those who are "charged with criminal offence". This would seem to preclude its application to pretrial procedures such as police interrogation ${ }^{6}$. However, in Imbrioscia $v$ Switzerland ${ }^{7}$ the Court indicated that:

"[t]he primary purpose of Article 6 (art. 6) as far as criminal matters are concerned is to ensure a fair trial by a "tribunal" competent to determine "any criminal charge", but it does not follow that the Article (art. 6) has no application to pre-trial proceedings ... Article 6 (art. 6) -

\footnotetext{
${ }^{5}$ Article 6 (1) provides "In the determination of his civil rights and obligations or of any criminal charge against him, everyone is entitled to a fair and public hearing within a reasonable time...". In addition, Article 6(3), which enumerate additional protection, states that "Everyone charged with a criminal offence has the following minimum rights...".

${ }^{6}$ In the commission's view, a person becomes "charged" for Article 6 purposes at the point when he is "substantially affected" by the proceedings taken against him (ECtHR 27 February 1980, Deweer v. Belgium, (no. 6903/75), § 46).

${ }^{7}$ ECtHR 24 November 1993, Imbrioscia v. Switzerland, (no. 13972/88), § 36.
} 
especially of paragraph 3 (art. 6-3) - may also be relevant before a case is sent for trial if and in so far as the fairness of the trial is likely to be seriously prejudiced by an initial failure to comply with them."

Even as acknowledging that "the investigation proceedings are of great importance for the preparation of the trial" 8 , many scholars have found that the Strasbourg authorities were careful to avoid announcing a general principle on whether the full panoply of rights under Article 6 was applicable at the stage of a preliminary investigation, notably the police interrogation (Toney, 2001; Summers, 2007; Jackson, 2009a, 2009b). The reasons are many, but the most plausible explanation lies in the Court's acknowledgment of criminal proceeding as involving two distinct stages - trial and pretrial stage-and of the consequent differences in the nature of the rights that are required in the respective phase (Summers, 2007).

Instead, the Court has interpreted Article 6 to include the right to remain silent and the privilege against self-incrimination as part of the fair trial standard, and in a series of cases $^{9}$ has been crafting a set of jurisprudence to define how much the Convention will protect an individual charged with criminal offenses despite state efforts to the production of incriminating evidence.

\subsection{The Right to Remain Silent and the Privilege against Self-incrimination}

Currently in Europe, in both common law and civil law traditions, there is a near-universal agreement on the importance of the right to remain silent and privilege against self-incrimination as effective safeguards in police questioning for individuals suspected of having committed a crime (Van Kessel, 1998: 804; Jackson, 2005: 835). Although the Convention contains no explicit guarantee of these immunities, in Funke $v$ France $^{10}$ the Court gave an important symbolic statement of the significance of the right to remain silent and the privilege against self-incrimination, the Court repeatedly stated that ${ }^{11}$ :

\footnotetext{
${ }^{8}$ Can v. Austria, 8 Eur. H.R. Rep. 14, para. 53 (1985) (Commission report).

${ }^{9}$ In the following, the paper traces the series of cases concerning the right to remain silent and the privilege against self-incrimination to examine the rationale put forward by the Court. See, for instance, ECtHR 25 January 1996, John Murray v. The United Kingdom, (no. 41/1994/488/570), ECtHR 29 November 1996, Saunders v. The United Kingdom, (no. 43/1994/490/572), ECtHR 5 February 2003, Allan v. The United Kingdom, (no. 48539/99), and ECtHR 27 November 2008, Salduz v. Turkey, (no. 36391/02).

${ }^{10}$ ECtHR 25 February 1993, Funke v. France, (no. 10828/84), § 44.

${ }^{11}$ ECtHR 25 January 1996, John Murray v. The United Kingdom, (no. 41/1994/488/570), § 45. ECtHR 29 November 1996, Saunders v. The United Kingdom, (no. 43/1994/490/572), § 68.
} 


\begin{abstract}
"Although not specifically mentioned in Article 6 (art. 6) of the Convention, there can be no doubt that the right to remain silent under police questioning and the privilege against selfincrimination are generally recognized international standards which lie at the heart of the notion of a fair trial ... By providing the accused with protection against improper compulsion by the authorities these immunities contribute to avoiding miscarriages of justice and to securing the aims of Article 6."
\end{abstract}

The absence of specific provisions establishing the right and the privilege under the Convention has enabled the Court to be quite flexible about the confession standards that are to be equated with Article 6, permitting the Court to develop its distinctive set of parameters to define the reach of these immunities. As we saw in the previous section, the police questioning process involves conflicting values, aims, and interests: law enforcement has an interest in obtaining a confession or incriminating statement from the guilty to lead to the solution of crimes and individuals should be protected from abusive or overreaching interrogation practices. The two sides may clash and yet at the same time depend on each other for legitimacy. Although all legal systems in Europe provide for the respect of the rights of the defence during interrogation proceedings, in balancing the public interest in crime control against individual interest in freedom from police coercive tactics, the civil law and common law systems adopt significantly different ways. Yet no one can say that the procedure in either civil or common law models is superior to the other both with regards to its fact-finding precision and its fairness. Importantly, the Court itself did not set out with any presumption that the common law concept of a "fair" police questioning is superior to the civil law concept, or the latter superior to the former (Summers, 2007, 98). In drawing attention to shortcomings in the procedures of national systems, the Court has tried to 'translate' the right to remain silent and the privilege against self-incrimination in such a manner as to make them amenable to diverse institutional frameworks of its Contracting States and accommodation within both common law and civil law traditions.

\title{
3.2.1 The Scope of the Right and the Privilege
}

The need to balance important competing interests requires the Court to develop standards for determining when the setting in which incriminating information is sought is sufficient to warrant application of the right and the privilege. And the degree to which limitations may be put upon the exercise of these immunities would seem to depend on how broad the scope of the immunities is considered to be. Although the right and the privilege were enunciated early on Funke $v$ France ${ }^{12}$, the scope of the immunities has undergone development and refinement over the years.

${ }^{12}$ ECtHR 25 February 1993, Funke v. France, (no. 10828/84). 
In the case of Funke, the Court based its acceptance of the right and the privilege on its view of the generally accepted European jurisprudence principles (Berge, 2006). However, nothing was said about the scope of the immunities, or about their nature and rationales. Some three years passed, during which the implications of Funke judgment were unclear, before the topic again attracted the attention of the Court. In John Murray $v$ United Kingdom, the Court made it clear that warning suspects that adverse inferences may be drawn against them at their trial amounted to an indirect form of compulsion that did not necessarily destroy the very essence of the privilege. The Court went on to state that "the right to remain silent" was not absolute, in the sense that the immunities could and should not prevent the accused's silence from being taken into account in situations that clearly called for an explanation ${ }^{13}$.

Whereas the John Murray decision confirmed the place of the right and the privilege in European human rights law, the scope of these immunities still awaited a detailed examination by the Court. This was not long in coming, in the case of Saunders v. United Kingdom ${ }^{14}$, decided in 1997. The case of Saunders concerned the use of statements made at the applicant's criminal trial, which had been obtained under local compulsion under the Company Act 1985. In the instant case, the Court noted that testimony obtained under compulsion that appears on its face to be of a nonincriminating nature - such as exculpatory remarks or mere information on questions of fact - may later be deployed in criminal proceedings in support of the prosecution, for example, to contradict or cast doubt upon other statements of the accused or evidence given by him or her during the trial or to otherwise undermine the suspect's credibility. Where the credibility of an accused must be assessed by a jury, the use of such testimony may be especially harmful. It concluded that the privilege cannot reasonably be confined to statements of admission of wrongdoing or to remarks that are directly incriminating ${ }^{15}$. Further, in referring to the case of John Murray and Funke, the Court held that the privilege against self-incrimination "is primarily concerned with respecting the will of an accused person to remain silent ${ }^{16 "}$. It did not extend to the use in criminal proceedings of material that may be obtained from the accused through the use of compulsory powers but which has an existence independent of the will of the suspect, such as breath, blood, and urine samples ${ }^{17}$.

The Court's approach was developed in Allan $v$ United Kingdom, where an undercover police officer had been placed in the applicant's cell for some weeks for the specific purpose of eliciting from the applicant information implicating

\footnotetext{
${ }^{13}$ ECtHR 25 January 1996, John Murray v. The United Kingdom, (no. 41/1994/488/570), § 47.

${ }^{14}$ ECtHR 29 November 1996, Saunders v. The United Kingdom, (no. 43/1994/490/572).

${ }^{15}$ Ibid. § 71 .

${ }^{16}$ Ibid. § 69 .

${ }^{17}$ Ibid. $§ 69$.
} 
the suspect in a murder. The Court began its consideration with the following statement of principle: "In examining whether a procedure has extinguished the very essence of the privilege against self-incrimination, the Court will examine the nature and degree of the compulsion, the existence of any relevant safeguards in the procedures and the use to which any material so obtained is put. ${ }^{18 "}$ Applying this approach to the facts of the case, the Court defined the scope of the right and the privilege in the following terms:

"While the right to silence and the privilege against self-incrimination are primarily designed to protect against improper compulsion by the authorities and the obtaining of evidence through methods of coercion or oppression in defiance of the will of the accused, the scope of the right is not confined to cases where duress has been brought to bear on the accused or where the will of the accused has been directly overborne in some way. The right, which the court has previously observed is at the heart of the notion of fair procedure, serves in principles to protect the freedom of a suspected person to choose whether to speak or to remain silent when questioned by the police. ${ }^{19 \prime}$

We have seen that the Court explained that the scope for the immunities is twofold. First, specifically, it protected the accused against abusive coercion inquires by the authorities. Secondly, in principle, it supported and defended the will of an accused person to speak or to remain silent during police questioning. Thus the focus of the case law has been on attempting to distinguish cases of improper compulsion from cases where the accused should have been able to reach an autonomous decision when he is called upon to answer criminal allegations. The robustness of this rationale will be discussed below.

\subsubsection{Improper Compulsion}

As regard to the nature and degree of the improper compulsion in police questioning to obtain the incriminating statements, first, prohibition on torture and other forms of inhuman and degrading treatment are not open to question. All European countries prohibit the use or threat of violence and require exclusion of confessions so obtained (Herrmann, 2008). Apart from this, however, countries differ as to what constitute improper compulsion, as we observed in the previous section, with some countries focusing more on the need to prevent unreliable confessions and some focusing more on deterring improper police practices. Notably, the Court stated explicitly in Murray that it did not consider it prudent to "give an abstract analysis of the scope of these immunities" and, in particular, "of what constitutes 'improper compulsion"' 20.

Nevertheless, in Heaney and McGuinness $v$ Ireland, the Court held that there had been a violation of the privilege against self-incrimination, where the

\footnotetext{
${ }^{18}$ ECtHR 5 February 2003, Allan v. The United Kingdom, (no. 48539/99), § 44.

${ }^{19}$ Ibid. § 50 .

${ }^{20}$ ECtHR 25 January 1996, John Murray v. The United Kingdom, (no. 41/1994/488/570), § 46.
} 
applicants were convicted and imprisoned for failing to account for their movements. The Court held that the "degree of compulsion" imposed on the applicants by the legal obligations with a view to compelling them to provide information relating to charges against them "destroyed the very essence" of their privilege against self-incrimination and their right to remain silent ${ }^{21}$. Furthermore, noting that the United Kingdom government's claim of the terrorist nature and complexity of the alleged offences, the Court concluded that the public interest could not be relied on to justify a provision that extinguished this essence ${ }^{22}$.

Moreover, the Court found no distinction between the imposition of criminal sanctions themselves and the threat to impose them. The threat of criminal prosecution was at issue in Saunders, where the accused was convicted on a number of counts of fraud relating to share dealing. During the investigation of the offence, the trade and industry inspectors relied on section 434(5) of the Companies Act 1985, which made it a possible contempt of court to refuse to produce documents or answer questions posed by fraud investigators, and provided that the answers to such questions may be used in evidence against him at trial. Thus Saunders was faced with either incriminating himself or being in contempt of court, an unenviable dilemma. In this case, the Court concluded that the privilege was violated when statements, which were extracted from the accused by the investigators under threat of contempt of court, were subsequently used against the accused in court ${ }^{23}$. The Court rejected the government's argument that the right and the privilege could be balanced on some pressing ground of public interest such as the need to investigate and punish fraud. The fairness requirement of Article 6 meant that the immunities applied to all types of criminal proceedings without distinction from the most simple to the most complex ${ }^{24}$.

These cases demonstrate a clear type of compulsion, where the suspect's silence amount to a criminal offence. In another words, the cases reveal that under Article 6 of the Convention there should be no duty imposed on individual suspects, backed by a sanction, to answer the questions of state officials in relation to criminal charges against them. Moreover, this approach also suggests that when an infringement becomes an issue of the "essence of the privilege", it can never be justified by the security and public order concerns.

\footnotetext{
${ }^{21}$ ECtHR 21 March 2001, Heaney and McGuinness V. Ireland, (no. 34720/97), § 55.

22 Ibid. § 57-58.

${ }^{23}$ ECtHR 29 November 1996, Saunders v. The United Kingdom, (no. 43/1994/490/572), § 7576.

${ }^{24}$ Ibid. § 74 .
} 
All of this presupposes a particular relationship between the citizen and the state and its officials in the context of criminal justice. According to Redmayne (2007: 221), the emphasis on the importance of not compelling the individual suspects with legal obligations to supply oral evidence for the purpose of prosecution has underlined the necessity of limiting the scope of prosecution powers in a liberal democracy as this is when the State is at its most powerful. The underlying rationale is that if the suspect was under an obligation to cooperate in whatever way in bringing about his or her own conviction in the course of police questioning, then the duty of the prosecution to establish guilt beyond reasonable doubt would be watered down and even contradicted by the duty imposed on the suspect (Ashworth, 2008). On this view, the right and the privilege, that is, by guaranteeing individual suspects of not being compelled by the threat of criminal sanctions to answer incriminating questions, are considered to act as useful brakes on the untrammelled power of investigation by the law enforcement officials (Hogan, 1997: 75). In addition, not only might the immunities be considered to act as useful brakes on the untrammelled state power but statements made under pressure may be unreliable. As will be discussed later in the article, their worth is also in the avoidance of miscarriages of justice.

However, in a recent road traffic case O'Halloran and Francis $v$ United Kingdom, the Court did not seem to follow a consistent line or to relate well to the Saunders principles by holding that it could not accept that any direct compulsion requiring a suspect to make incriminatory statements automatically results in a violation ${ }^{25}$. The central issue in each of two applications brought in this case was whether the privilege was violated when the registered owner of a car was required under United Kingdom road traffic law to furnish the name and address of the driver of the car when it was caught speeding on camera and, whether this evidence could be used in a prosecution. Notably, failure to give the information was an offense punishable by a fine and by penalty points on the driving license. The Grand Chamber, by fifteen votes to two, held that there was no violation of Article 6. Although all cases of direct compulsion, as noted above, had been held to violate the privilege in the past, the Court held that this is not a necessary conclusion, and that other factors would be taken into account in determining whether the essence of the privilege against self-incrimination has been violated such as the nature and degree of the compulsion used to obtain the evidence, the existence of any relevant safeguards in the procedure, and the use to which any material so obtained was put ${ }^{26}$. Having regard to these factors, particularly the special nature of the regulatory regime at issue and the limited nature of the information required, the Court held that the essence of the

\footnotetext{
${ }^{25}$ ECtHR 29 June 2007, O'Halloran and Francis v. The United Kingdom, (nos. 15809/02 and 25624/02), §53.

${ }^{26}$ Ibid. § 55 .
} 
applicants' right to remain silent and privilege against self-incrimination had not been destroyed, and thus there was no violation of Article 6 .

Apparently, in this case, the Grand Chamber allowed direct compulsion to be outweighed by other factors. Should this be a cause of concern? Does this judgment suggest any loosening of the right and the privilege? According to Ashworth (2008: 765), it would be preferable to recognize it as a discrete exception. This might be supported by Judge Borrego's concurring opinion in the instant $\operatorname{case}^{27}$, arguing that a citizen who chooses to own and drive a car "accepts the existence of the motor vehicle regulations and undertakes to comply with them in order to live as a member of society. These regulations clearly entail certain responsibilities." Perhaps more importantly, there is a European consensus that the immunities should not apply in this situation (Ashworth, 2008, 763).

\subsubsection{Freedom to Choose}

Europeans today generally recognize the rule against the use of criminal sanctions to compel a person to answer questions in the criminal process; however, vast differences remain within the states concerning the nature and scope of the right to remain silent and the privilege against self-incrimination (Van Kessel, 1998). More specifically, there is less agreement within the Contracting States with respect to how far, short of coercion or oppressive methods, authorities may go to persuade or encourage individual suspects to speak during pretrial interrogations. Two issues generate the most controversy: (1) to what extent may a suspect be disadvantaged from silence, and (2) what procedural safeguards must be afforded to a suspect in pretrial interrogation, such as warning of the right to silence and the right to counsel. As the rights of the defence are procedural rights, their applications in practice depend to a larger extent on the legal system under which the case is to be adjudicated. Therefore, the interplay of policies at work in balancing state and individual interest is likely to vary as the setting changes.

Nevertheless, in both common law and civil law traditions, it has long been recognized that only voluntary confessions can be admitted as evidence (Ma, $2007,5)$. The classic protection for common law criminal suspects in police questioning has been the voluntariness test according to which confessions have to be voluntary before they can be admitted as evidence. In King $v$. Warickshall (1783: 235), the court eloquently explained "a free and voluntary confession is deserving of the highest credit because it is presumed to flow from the strongest sense of guilt and therefore it is admitted as proof of the crime to which it refers; but a confession forced from the mind by the flattery of hope or by the torture of fear comes in so questionable a shape when it is to be considered as the evidence

${ }^{27}$ Ibid. 
of guilt that no credit ought to be given to it; and therefore it is rejected." On the European continent, despite torture having been part of the ordinary criminal procedure and regularly permitted to be employed to investigate and prosecute routine crime before the ordinary courts in the inquisitorial system, the use of coercion was legally abolished throughout the continent during the eighteenth and nineteenth centuries (Langbein 1977; Einolf 2007).

Clearly, the British Court's explanation expresses the view that the exercise of free will through a voluntary confession is the best indication of the truth autonomy if you like guarantees truth. Arguably, one of the difficulties of this substantive rationale here, however, is that voluntariness and consent are 'meaningless' in police questioning where all the choices available to suspects are unpleasant (Sanders and Young, 2007, 247). At any rate, many interrogations are stressful and unpleasant, where the police, who acknowledge the reason they arrested and kept the suspect in police custody for questioning, may give the suspect the feeling that the interrogation will be lengthy until the suspect provides the interrogators with answers that satisfy them (Kitai-Sangero, 2008). Indeed, a suspect's confession to the police is not voluntary in the same way as a spontaneous confession to a clergyman; in this sense, no admission of guilt is voluntary (Seidman, 1992).

Seen in this way, the substantive dimension of voluntariness is extraordinarily difficult to assert in the coercive atmosphere of a custodial interrogation. In fact, Contracting States have upheld the possibility to conduct custodial interrogations by establishing safeguards that supposedly 'dispel' the inherent coercion that it entails. Most notably, the Court, in the earlier case of John Murray v United Kingdom, has stated that "a certain level of indirect compulsion" is permissible ${ }^{28}$. However, after the case of John Murray, the Court did not reaffirm an approach that would justify certain "proper compulsion" as only where they do not become an issue of the "essence of the privilege". The underlying reasoning may be that if it is acknowledged that a certain degree of compulsion during an interrogation is legitimate, then it is difficult to determine when the applied pressure crosses the boundary of the permissible.

Actually, the Court went far beyond the traditional voluntariness test by differentiating between acceptable and unacceptable police behaviour when it decisively ruled that a custodial interrogation is inherently coercive. In the case of Magge $v$ United Kingdom the applicant was detained and access to legal advice was delayed for 48 hours. The Court noted that the "intimidating atmosphere [of a custodial interrogation] specifically devised to sap his will and make him confess to his interrogators" ${ }^{29}$. Notwithstanding this conclusion, the Court attempted to preserve the autonomy of the suspect in a manner that would

\footnotetext{
${ }^{28}$ ECtHR 25 January 1996, John Murray v. The United Kingdom, (no. 41/1994/488/570), § 50.

${ }^{29}$ ECtHR 6 June 2000, Magee v. The United Kingdom, (no. 28135/95), § 43.
} 
allow the police to continue conducting custodial interrogations. In John Murray, the Court stated that the right to remain silent was not an absolute guarantee against any and all government efforts to secure information from a suspect during interrogations $\mathrm{s}^{30}$. The Court assumed that by means of legal assistance it would ensure that a suspect's confession was a reflection of his or her true will to cooperate.

According to this rationale, the right and the privilege are designed to protect the suspect's right to reach an autonomous decision by means of legal assistance. In drawing attention to shortcomings in the procedures of national systems, the Court has had to develop its vision of defence rights in a piecemeal fashion, case by case, proceeding on the basis, as the Court has done throughout its jurisprudence, that the Convention is a living instrument that requires adaptation as circumstances change ${ }^{31}$. Nevertheless, it is possible to identify three broad standards in the development of its distinctive version of the immunities. In the following, these three standards will be analyzed with the object of throwing some light upon the practical value of the guarantee provided therein and of identifying some of the questions left open by the Court judgments to date.

\section{Access to a lawyer from the first police interrogation}

First, as a rule, access to a lawyer should be provided from the first interrogation of a suspect by the police. In the Court's opinion, early access to a lawyer is part of procedural safeguards to which the Court will have particular regard when examining whether a procedure has extinguished the very essence of the privilege ${ }^{32}$. The reasons why the Court considers the right of early access to legal counsel to be so important are to be found in a passage in Salduz $v$ Turkey, which has been restated in a number of subsequent judgments ${ }^{33}$ :

"The Court underlines the importance of the investigation stage for the preparation of the criminal proceedings, as the evidence obtained during this stage determines the framework in which the offence charged will be considered at the trial ... At the same time, an accused often finds himself in a particularly vulnerable position at that stage of the proceedings, the effect of which is amplified by the fact that legislation on criminal procedure tends to become increasingly complex, notably with respect to the rules governing the gathering and use of evidence. In most cases, this particular vulnerability can only be properly compensated for by the assistance of a lawyer whose task it is, among other things, to help to ensure respect of the right of an accused not to incriminate himself. This right indeed presupposes that the prosecution in a criminal case seek to prove their case against the accused without resort to

\footnotetext{
${ }^{30}$ ECtHR 25 January 1996, John Murray v. The United Kingdom, (no. 41/1994/488/570), § 47.

${ }^{31}$ ECtHR 25 April 1978, Tyrer v. The United Kingdom (no. 5856/72), § 31.

${ }^{32}$ ECtHR 27 November 2008, Salduz v. Turkey, (no. 36391/02), § 54.

${ }^{33}$ Ibid. § 54-55.
} 
evidence obtained through methods of coercion or oppression in defiance of the will of the accused.

Against this background, the Court finds that in order for the right to a fair trial to remain sufficiently "practical and effective" Article $6 \S 1$ requires that, as a rule, access to a lawyer should be provided as from the first interrogation of a suspect by the police, unless it is demonstrated in the light of the particular circumstances of each case that there are compelling reasons to restrict this right."

In fact, there are two kinds of rationales mentioned that are somewhat mixed together: what has been described as a protective rationale that the right of early access to a lawyer is needed to ensure that suspects are not coerced into making confessions and a participative defence rationale that claims that lawyer is needed in advising on the complexities of gathering and using evidence to achieve an effective defence.

The protective rationale would seem to highlight the Court's acknowledgment of the inherent coercive nature of the custodial interrogation. In a recent case, Pishchalnikov $v$ Russia, the Court held that the police, prosecution authorities, and experts in the field of criminal proceedings are well-equipped with various, often psychologically coercive, interrogation techniques that facilitate, or even prompt, receipt of information from an accused. In the instant case, the Court observed that, having been denied legal assistance, the applicant in the first few days after arrest had been subjected to intense interrogations by the police who are in an effort to generate evidence aiding the prosecution's case $^{34}$. With these facts in mind, the Court considered there is no evidence that the confessions made by the applicant during those interrogations were initiated by the suspect ${ }^{35}$. In the Court's view, "if an accused has no lawyer [during police interrogation], he has less chance of being informed of his rights and, as a consequence, there is less chance that they will be respected" ${ }^{\prime 3}$. It is certainly arguable that in custodial interrogation the potential for systemic abuse of law enforcement powers is at its greatest (Toney, 2001). Empirical study of police detectives reveals that they are anything but neutral or impartial in their collection and construction of case evidence against criminal suspects during the interrogation process (McConville, Sanders, and Leng, 1991; Williams, 2000; Cape, Hodgson, Prakken, and Spronken, 2007).

The participative defence rationale, which would seem to be the primary concern, highlights the Court's acknowledgment of the important impact the interrogation stage may have for the subsequent criminal proceedings, the vulnerable position that the suspects are in, and of the need of lawyer help therefore to achieve an effective defence. Noticeably, in Salduz, the Court

${ }^{34}$ ECtHR 24 December 2009, Pishchalnikov v. Russia, (no. 7025/04), § 86.

${ }^{35}$ Ibid. $\S 80$.

${ }^{36}$ Ibid. § 78 . 
expressly linked the right of access not only to the need to protect the accused against abusive conduct on the part of the authorities and the prevention of miscarriages of justice but also to the fulfilment of the aims of Article 6, notably "equality of arms between the investigating or prosecuting authorities and the accused" ${ }^{37}$. Equality of arms, an old principle with roots in both common law and civil law traditions, is a principle that has been expressed as affording every party to the proceedings "a reasonable opportunity to present his case in conditions that do not place him at substantial disadvantage vis-a-vis his opponent" ${ }^{\prime \prime 38}$.

Although traditionally the principle of equality of arms has been reserved for the trial, there seems to have been widespread realization that the examination of evidence did not always occur at the court (Summers, 2007, 28). In both common law and civil law systems, the police are permitted to detain persons suspected of committing crimes to interrogate them before deciding whether and when to initiate criminal proceedings and to produce them before the court (Kitai-Sangero, 2008). Unless the prosecution is prevented from using the information obtained in custodial interrogation as evidence, the police are likely to regard interrogation as an important opportunity to obtain evidence to be used to encourage suspects to plead guilty or to be used against them at their trials. Such evidence may be in the form of a confession, but may alternatively be in the form of an inconsistent account given by the suspect, demonstrating lies told by the suspect, or even failure to answer questions put by the police (Cape, 2002, 113).

The situation in the interrogation room is compounded by the fact that suspects normally want to provide an account of themselves (Jackson, 2009a, 850). Nearly every European Continental country today has adopted rules that technically prohibit courts from drawing unfavourable inferences from a suspect's silence, with England, Scotland, and Norway being exceptions (Van Kessel, 1998). However, in practice, in most jurisdictions, irrespective of whether there is a rule against adverse inferences from silence or not, most suspects do speak to the police or testify during interrogations (Van Kessel, 1998; KitaiSangero, 2008; Jackson, 2009a). Scholars realized that suspects feel pressure to speak because silence can be considered as an act of noncooperation with the authorities, which can do the suspect little good in terms of decisions that affect his or her liberty or that affect the level of the charge brought (Damaska, 1973; Dixon, 1991; Jackson, 2009a).

In the Court's view, the defence right to speak for oneself is a double-edged sword with the potential to count against the suspect. In Pishchalnikov, the Court reiterated that the criminal law - substantive as well as procedural - and

\footnotetext{
${ }^{37}$ ECtHR 27 November 2008, Salduz v. Turkey, (no. 36391/02), § 53.

${ }^{38}$ ECtHR 17 February 1997 Foucher v. France, (no. 10/1996/629/812), § 34.
} 
criminal proceedings are a rather complex and technical matter that is often incomprehensible to laypersons, such as the suspect ${ }^{39}$. In the absence of assistance by counsel, who could have provided legal advice and technical skills, the applicant was unable to make the correct assessment of the consequences the decision to confess would have on the outcome of the criminal case ${ }^{40}$. Moreover, practically at every stage of criminal proceedings decisions have to be taken, the wrong decision being able to cause irreparable damage. Hence the Court concluded reliable knowledge of law and practice is usually required to assess the consequences of such decisions ${ }^{41}$.

Further, in emphasizing the importance of the appearance of justice, the Court drew attention to the increased sensitivity of the public to the fair administration of criminal justice: "it is of fundamental importance in a democratic society that the courts inspire confidence in the public and above all, as far as criminal proceedings are concerned, in the accused. ${ }^{42 \prime \prime}$ It is noticed that "an ultimately successful appeal against conviction, secured on the basis of the absence of legal advice meant that a confession made to a police officer was unreliable, which is determined following months, if not years, in pre-trial detention, is likely to leave the accused resentful and distrustful not just of the police, but of the whole criminal justice apparatus (Cape et al. 2010, 4)." In Pishchalnikov $v$ Russia, the applicant was arrested on suspicion of aggravated robbery. He was interrogated - both on the day of his arrest and immediately on the following day -in the absence of a lawyer, although he had clearly indicated a defence counsel he wanted to represent him. During these interrogations the applicant confessed to having taken part in the activities of a criminal group that included a murder, kidnapping, hijacking, and unlawful possession of weapons. The Court considered it unlikely the applicant could reasonably have appreciated the consequence of his proceeding to be questioned without the assistance of counsel ${ }^{43}$.

Certainly, Russia is not an exception. Although the right to contact a lawyer after arrest exists in most Contracting States, there is a great divergence as to the moment at which the right to a lawyer can be effected (Spronken, Vermeulen, De Vocht and Van Puyenbroeck, 2009, 38). In a considerable number of countries, such as Belgium, Austria, and Germany, the right to counsel is not possible immediately after arrest but only at a given stage of the investigative proceedings. The Court indicated that even where compelling reasons may exceptionally justify denial of access to a lawyer, such restriction - whatever its justification -must not unduly prejudice the rights of the accused under Article

\footnotetext{
${ }^{39}$ ECtHR 24 December 2009, Pishchalnikov v. Russia, (no. 7025/04), § 84.

${ }^{40}$ Ibid. § 85 .

${ }^{41}$ Ibid. § 84 .

${ }^{42}$ ECtHR 11 March 2009, Panovits v. Cyprus, (no. 4268/04), § 97.

${ }^{43}$ ECtHR 24 December 2009, Pishchalnikov v. Russia, (no. 7025/04), § 80.
} 
6. The Court further considered that the lack of legal assistance during a suspect's interrogation would constitute a restriction of his or her defence rights, and that these rights will in principle be irretrievably prejudiced when incriminating statements made during police interrogation without access to a lawyer are used for a conviction ${ }^{44}$. This new interpretation of Article $6 \S 3$ of the Convention, referred as the "Salduz doctrine", has been confirmed in several subsequent judgments.

\section{Waiver standard for the right to counsel}

Second, the right to counsel from the first police interrogation, being a fundamental right among those that constitute the notion of fair trial and ensuring the effectiveness of the rest of the foreseen guarantees of Article 6 of the Convention, is a prime example of those rights that require the special protection of the knowing and intelligent waiver standard ${ }^{45}$. The Court does not rule out that a suspect may himself waive the right to legal assistance and respond to interrogations ${ }^{46}$. But the Court emphasized in Pishchalnikov that such a waiver "must not only be voluntary, but must also constitute a knowing and intelligent relinquishment of a right. Before an accused can be said to have implicitly, through his conduct, waived an important right under Article 6, it must be shown that he could reasonably have foreseen what the consequences of his conduct would be" ${ }^{47}$. In the Court's view, a valid waiver cannot be established by showing only that a suspect responded to further police-initiated interrogation even if he or she has been reminded of the right to remain silent and signed the form stating these rights. Somewhat akin to the Miranda rules ${ }^{48}$, when a suspect has invoked the right to be assisted by counsel during

\footnotetext{
${ }^{44}$ ECtHR 27 November 2008, Salduz v. Turkey, (no. 36391/02), § 55.

45 ECtHR 27 November 2008, Salduz v. Turkey, (no. 36391/02); ECtHR 11 March 2009, Panovits v. Cyprus, (no. 4268/04); ECtHR 2730 June 2009, PŁonka v. Poland, (no. 20310/02); ECtHR 24 December 2009, Pishchalnikov v. Russia, (no. 7025/04).

${ }^{46} 30$ November 2000, Kwiatkowska v. Italy (dec.), (no. 52868/99).

${ }^{47}$ ECtHR 24 December 2009, Pishchalnikov v. Russia, (no. 7025/04), § 77.

${ }^{48}$ The Miranda Court established a general rule that once a suspect indicates that he or she does not wish to be interrogated, the police must ease all questioning (Van Kessel, 1998). With respect to whether the police may make attempts to obtain a waiver of the right to remain silent from a suspect, the U.S. Court in subsequent decisions made a distinction between the situation when a suspect asserts his or her right to remain silent and the situation when the right to counsel is invoked ( $\mathrm{Ma}, 2007)$. If a suspect asserts only the right to remain silent, the police may resume questioning after a substantial time lapse so long as they properly advise the suspect of the Miranda rights prior to interrogation (Michigan $v$. Mosley, 1975). But once a suspect has invoked the right to counsel under Miranda, there can be no further interrogation until counsel has been made available unless defendant initiates further communications with police officers (Edwards v. Arizona, 1981; Arizona v. Roberson, 1988; Minnick v. Mississippi, 1990).
} 
interrogation, the Court is of the opinion that the suspect should not be subject to further interrogation by the authorities until counsel has been made available to the suspect, unless the suspect himself initiates further communication, exchanges, or conversations with the police or prosecution ${ }^{49}$.

A lawyer can not only ensure the legality of any measures taken in the course of the investigation proceedings, he can also provide advice and assistance on how to mount the most effective defence. It hence has been argued that such a rule allowing prior consultation with an attorney would make it virtually impossible for police to obtain confession evidence (Kitai-Sangero, 2008, 151). In the absence of empirical data either way, these arguments tend to consist of inflated claims about the effect of the lawyer as an obstacle for convicting the guilty without enough attention being given to the procedural context in which the right operates ${ }^{50}$. In fact, when a reasonable explanation is given that could clear the suspect of all suspicion, a lawyer in most jurisdictions might advise the suspect to provide his or her version of the event because silence at the police station could increase the police interrogators' suspicion against the suspect (Damaska, 1973; Seidmann and Stain, 2000). Moreover, the fact that the suspect has not provided his or her version at the first opportunity available could weaken the credibility of a later version provided in court. Actually, various options are available at this stage as they are at the trial. One may suggest certain lines of exculpatory inquiry. One may be made aware that they have an opportunity to respond to certain allegations and all this information will enter into the totality of data on the basis of which guilt-determination will eventually be made. In recognition of the growth in nonjudicial disposals across a number of jurisdictions, the suspect would also be made aware of any informal disposals or decisions that may be made if they are prepared to make an admission to the allegations. As Jackson (2009a: 861) pointed out, "once the rights of the defence are put in place ... the right of silence reverts to an exercise of will or choice on the part of the individual accused, but a choice that is made on an informed basis as part of a defence strategy which is taken in full recognition of the costs and benefits of its exercise."

\section{The quality of the defence lawyer's work}

Third, as a general rule, a state cannot be held responsible for every shortcoming on the part of a lawyer appointed for legal aid purposes. The Convention does not contain any explicit provision regarding the role, or standards, of criminal defence lawyers. As regards the quality of the work of a defence lawyer, the Court has been reluctant to hold the State liable for the

\footnotetext{
${ }^{49}$ Ibid. § 79.

${ }^{50}$ In fact, there is some evidence from England and Wales that lawyers do not routinely advise their clients not to confess, and do not routinely advise their clients to remain silent (Sanders, Young, and Burton, 2010).
} 
failures of a lawyer's defence. In Imbrioscia, the Court stated explicitly that "owing to the legal profession's independence, the conduct of the defence is essentially a matter between the defendant and his representative; under Article 6 para. 3 (c) the Contracting States are required to intervene only if a failure by counsel to provide effective representation is manifest or sufficiently brought to their attention" 51 . In the court's opinion, as a rule, access to a lawyer should be provided as from the first interrogation of a suspect by the police; however, it is not for the Court to speculate on the impact that a suspect's access to a lawyer during police custody would have had on the ensuing proceedings ${ }^{52}$. It is unlikely that the Convention protects the legally aided suspect who, ex post facto, challenges a legal adviser's reasonable exercise of discretion or tactical decision.

During the all important pretrial investigation, there are important legal and ethical constraints upon the lawyer's ability to prepare the defence case. The equality of the defence is, of course, linked inextricably to the legal procedural role that the lawyer might properly be expected to play within the space allotted to him or her in the criminal process. In an adversarial procedure, we would expect the defence lawyer to have comprehensive freedom to investigate the case for the accused - to have early access to the suspect, interview witnesses, gather expert evidence, and so on. In inquisitorial procedure, where evidence gathering is the responsibility of a central judicial enquirer, the defence lawyer, who is subsidiary to that of the central enquirer, may mainly serve to ensure the legality of the proceedings. Closely linked to the ways in which the defence lawyer's function is defined and understood within criminal procedure, defence lawyers in Contracting States are most likely to adopt different defence strategies to achieve their clients' best interests. As Van Kessel (1998: 816) observed, defence lawyer in Netherlands, in which the judges possess both the power and motivation to reward those early confessors with noncriminal alternatives, generally advises suspects to cooperate and give their side of the case at an early stage in the proceedings.

Importantly, any defence strategy cannot be implemented in a meaningful way without disclosure of relevant evidence. The 'cat and mouse' game played at custodial interrogation, in which police use of evidence plays a significant part, may deprive the suspect of adequate facilities for the preparation of a defence (Toney, 2001). Legal advisers need adequate details of the case against the suspect to advise the suspect effectively on such important matters as whether to remain silent or whether to respond to certain allegations that have arisen against the suspect. As explained earlier, there are various options available at the pretrial stage as at the trial. Hence, if there are no clear

\footnotetext{
${ }^{51}$ ECtHR 24 November 1993, Imbrioscia v. Switzerland, (no. 13972/88), § 41.

52 ECtHR 27 November 2008, Salduz v. Turkey, (no. 36391/02), §58; ECtHR 2730 June 2009, PŁonka v. Poland, (no. 20310/02), § 40.
} 
procedures for the use and disclosure of evidence by the police at custodial interrogation, it is argued the lawyer's engagement in the defence or guilty plea procedure is likely to be little more than symbolic, lending credibility to the legal process rather than providing the suspect with an effective defence guarantee (Toney, 2001; Hodgson, 2006).

Yet the precise parameters of the requirement of disclosure of relevant information to the defence and the right to comment on the evidence during police interrogation remain uncertain in the Court's jurisprudence. In Rowe and Davis $v$ United Kingdom, the Court held that the full disclosure right is not absolute prior to trial, and there are competing interests such as national security or the need to protect witnesses at risk of reprisals or to keep secret methods of police investigation of crime, which must be weighed against the rights of the suspect. Nonetheless, the Court emphasized any limitation on disclosure must be "strictly necessary" and subject to procedural safeguards that compensate for the handicap imposed on the defence ${ }^{53}$.

We must bear in mind that consistent with the wide margin of appreciation afforded to the Contracting states, the Court's concern is not with procedural guarantee per se, but rather with their effect on the overall fairness of the proceedings ${ }^{54}$. The Court has permitted inroads to be made by domestic jurisdictions into the specific rights provided that the trial as a whole may be considered fair in an attempt to accommodate established procedures within the two prevailing traditions. Recent research shows that there appears to be no consensus so far between EU jurisdictions as to the precise formulation of pretrial disclosure (Cape et al. 2010). Nevertheless, most member states do give a right to the accused or their lawyers at the pretrial stage to information about the evidence, although the scope of the right varies enormously and, in particular, depend upon whether the jurisdiction has an adversarial or inquisitorial tradition (Spronken et al. 2009).

\section{Conclusion}

Since it came into force in 1953, the European Convention on Human Rights has served as a reflection of Europe's effort toward the establishment of common standards of individual human rights and freedoms. The forty-seven countries

\footnotetext{
${ }^{53}$ ECtHR 16 February 2000, Rowe and Davis v. The United Kingdom (no. 28901/95), § 61.

${ }^{54}$ ECtHR 25 January 1996, John Murray v. The United Kingdom, (no. 41/1994/488/570), § 44. Moreover, it should be noted that in Al-Khawaja and Tahery $v$ United Kingdom (ECtHR 20 January 2009, Al-Khawaja and Tahery v. The United Kingdom, (no. 26766/05 and 22228/06)), the Court stated explicitly that each element of Article $6 \S 3$ is one of the minimum rights which must be accorded to anyone who is charged with a criminal offence and each right in Article $6 \S 3$ is an express guarantee (§ 34).
} 
that are currently signatories to the Convention are subject to the jurisdiction of the European Court of Human Rights, which was established in 1959 in Strasbourg as a mechanism to interpret and enforce the obligations created by the Convention. Although the Convention contains no explicit reference to the right to remain silent and the privilege against self-incrimination, the Court, drawing its rationale from Article 6 of the Convention, has been steadily developing its distinctive vision of the right and the privilege in an attempt to create a doctrine that sets a limit below which contracting parties could not allow their legal systems to fall, and at the same time accords with the established procedures within the civil law and common law traditions of its Contracting States.

The scope of the Court's distinctive vision of the right to remain silent and the privilege against self-incrimination is thus two-fold:

On the one hand, the Court has demonstrated its strong position for the core principle that state power should not be used to compel self-incrimination. In recent years, criminal procedure systems throughout Europe are being severely tested by the increasing ease of movement between European countries as well as by the problems of organized crime, drug trafficking and, most urgently, international terrorism. The tension between due process and crime control is inevitable, and it is at the time when a state exercises its law enforcement authorities that the substantive individual rights are most likely to clash with the state's interest in seeking the most effective means of crime control. Despite these challenges, the Court took the view that there should be no duty imposed on individual suspects, backed by a sanction, to answer the questions of state officials in relation to criminal offenses. Moreover, in evaluating selfincrimination challenges, the Court has also shown no inclination to balance the security and public order concerns when an infringement becomes an issue of the "essence of the privilege". The Court's position reflects a European commitment to respect individual human rights in the law enforcement process by requiring the domestic law of the Contracting States to keep within certain bounds.

On the other hand, the Court's perspective suggests that the suspect should have been able to reach an autonomous decision when called upon to answer criminal allegations. This stems from the Court's belief that the right to a fair hearing does not mean that the right to remain silent is absolute and the recognition of the privilege against self-incrimination is not incompatible with learning what happened from the suspect. It held that the right to have access to a lawyer should be provided as from the first interrogation of a suspect by the police while still permitting procedures that encourage defendants to meaningfully participate in the fact-finding process. Yet the precise parameters of the requirement of disclosure of relevant information to the defence and the right to comment on the evidence during police interrogation remain uncertain 
in the Court's jurisprudence. We must bear in mind that consistent with the wide margin of appreciation afforded to the Contracting States, the Court's concern is not with the essentiality for the special rights to be respected in every case, but rather with their effect on the overall fairness of the proceedings. As explained, despite the binding nature of the Court, the Court does not have jurisdiction to strike down national laws. It is up to the Contracting States to take steps to make necessary amendments in their domestic laws to bring them into compliance with the Convention provisions. As the rights of the defence are procedural rights, for safeguards in police questioning to be adequate and effective will in practice depend to a larger extent on each legal system's own historically developed institutions and the faith that different societies place in them ${ }^{55}$. Therefore, the Court, in an attempt to accommodate within both common law and civil law traditions the understanding of the defence lawyer's function and to adapt to diverse institutional frameworks of its Contracting States, has permitted inroads to be made into the right to disclosure by domestic jurisdictions provided the limitation on disclosure is viewed in proper perspective, such as for a favourable result for the accused.

Nevertheless, we would like to stress that although the scope of the right to disclosure is thereby left to the national authorities, their decisions remain subject to review by the Court for conformity with the fair trial requirement of the Convention. As indicated, it is no longer possible for proof processes to be dominated by judicial inquiry but neither is it possible for them to be dominated entirely by a trial contest between partisan parties refereed by a passive judge. The Court's approach that emphasizes the importance of legal assistance from the first interrogation of a suspect by law enforcement officials has enabled suspects to play an active role when they are being called upon to answer criminal allegations. This approach actually takes criminal procedure beyond the traditional boundaries of adversarial/inquisitorial discourse. Accordingly, both systems face new challenges and we may witness further divergence of existing pretrial proceedings as countries adapt their procedures to meet the demands of interrogation fairness laid down by the Court. However, controversy often remains as to whether the changes effected by the Contracting States are in full compliance with the decisions of the Court. So long as Contracting States' decisions remain subject to review by the Court, elements that are incompatible with the effective defence rights are likely to be subject to the Court's jurisprudence in the future. In this sense, the margin of appreciation gives the flexibility needed to avoid damaging confrontations between the Court and the Contracting States even as realizing a "uniform standard" of human rights.

\footnotetext{
${ }^{55}$ There is a growing interest among academics to analyze the changing political, economic and social factors to the development of the future professionalism within lawyers. See, for instance, Glasser, C. (1990), The Legal Profession in the 1990s-Images of Change. Legal Studies, 10(1), 1-11.
} 


\section{References}

Alschuler, A. W. (1997). A Peculiar Privilege in Historical Perspective. In Helmholz, R. H., Gray, C. M., Langbein, J. H., Moglen, E., Smith, H. E. \& Alschuler, A. W. (Eds.), The Privilege against Self-Incrimination: Its Origins and Development (pp. 181-204). Chicago: University of Chicago Press.

Ashworth, A. (2008). Self-Incrimination in European Human Rights Law-A Pregnant Pragmatism?. Cardozo Law Review, 30(3), 751-774.

Bárd, K. (2006). The role of the ECHR in shaping the European model of the criminal process. International Key Issues in Crime Prevention and Criminal Justice, $50,34-52$.

Berger, M. (2006). Europeanizing Self-incrimination: The Right to Remain Silent in the European Court of Human Rights. The Columbia Journal of European Law, 12(2), 339-381.

Bradley, C. M. (1999). Criminal Procedure: A Worldwide Study. Durham, N.C: Carolina Academic Press.

Brems, E. (2005). Conflicting Human Rights: An Exploration in the Context of the Right to a Fair Trial in the European Convention for the Protection of Human Rights and Fundamental Freedoms. Human Rights Quarterly, 27(1), 294-326.

Cape, E. (2002). Assisting and Advising Defendants Before Trial. In McConville, M. \& Wilson, G. P. (Eds.), The Handbook of the Criminal Justice Process (pp. 99-114). Oxford: Oxford University Press.

Cape, E., Hodgson, J., Prakken, T., Spronken, T. (2007). Suspects in Europe: Procedural rights at the investigative stage of the criminal process in the European Union. Ius commune Europaeum, 64. Antwerpen: Intersentia.

Cape, E., Namoradze, Z., Smith, R. \& Spronken, T. (2010). Effective Criminal Defence in Europe. Intersentia Uitgevers $\mathrm{N}$ V.

Damaska, M. (1973). Evidentiary Barriers to Conviction and Two Models of Criminal Procedure: A Comparative Study. University of Pennsylvania Law Review, 121(3), 506-589.

Dixon, D. (1991). Politics, Research and Symbolism in Criminal Justice: The Right of Silence and the Police and Criminal Evidence Act 1984. Anglo-American Law Review, 20, 27-38. 
Einolf, C. J. (2007). The Fall and Rise of Torture: A Comparative and Historical Analysis. Sociological Theory, 25 (2), 101-121.

Glasser, C. (1990), The Legal Profession in the 1990s-Images of Change. Legal Studies, 10(1), 1-11.

Guild, E. (2004). The Variable Subject of the EU Constitution, Civil Liberties and Human Rights. European Journal of Migration and Law, 6 (4), 381-394.

Jackson, J. D. (2005). The Effect of Human Rights on Criminal Evidentiary Processes: Towards Convergence, Divergence or Realignment? Modern Law Review. 68 (5), 737-764.

Jackson, J. (2009a), Re-Conceptualizing the Right of Silence as an Effective Fair Trail Standard. International and Comparative Law Quarterly. 58 (4), 835-861.

Jackson, J. (2009b), Autonomy and Accuracy in the Development of Fair Trial Rights. University College Dublin Law Research Paper No. 09/2009. Available at SSRN: http://ssrn.com/abstract $=1407968$

Jorg, N., Field, S., \& Brants, C. (1995). Are Inquisitorial and Adversarial Systems Converging? In Fnnell, P., Harding, C., \& Jorg, N. (Eds.), Criminal justice in Europe: A comparative study (pp. 41-56). Oxford: Clarendon Press.

Kitai-Sangero, R. (2008). Detention for the Purpose of Interrogation as Modern Torture. University of Detroit Mercy Law Review, 85(137), 137-162.

Harris, D. J. (1970). Recent Cases on Pre-Trial Detention and Delay in Criminal Proceedings in the European Court of Human Rights. The British Yearbook of International Law, 87-109.

Helmholz, R. H. (1997). Introduction. In Helmholz, R. H., Gray, C. M., Langbein, J. H., Moglen, E., Smith, H. E. \& Alschuler, A. W. (Eds.), The Privilege against SelfIncrimination: Its Origins and Development (pp. 1-16). Chicago: University of Chicago Press.

Herrmann, J. (2008). Implementing the Prohibition of Torture on Three Levels: The United Nations, the Council of Europe, and Germany. Hastings International and Comparative Law Review, 31(1), 437-460.

Hodgson, J. (2006) The Role of the Criminal Defence Lawyer in An Inquisitorial Procedure: Legal and Ethical Constrains. Legal Ethics, 1 (9), 125-144.

Hogan, G. (1997). Right to a Fair Trial - The Right to Silence and the Privilege against Self Incrimination - Article 6 European Convention on Human Rights - 
s436 Companies Act 1985 - Saunders v. UK: European Court of Human Rights. The British Yearbook of International Law, 71-77.

Lahti, R. (1999). Towards an international and European criminal policy?. Helsinki: Finnish Branch of the International Law Association.

Langbein, J. H. (1977). Torture and the Law of Proof: Europe and England in the Ancien Régime. Chicago: University of Chicago Press.

Langer, M. (2004). From Legal Transplants to Legal Translations: The Globalization of Plea Bargaining and the Americanization Thesis in Criminal Procedure. Harvard International Law Journal, 45, 1- 64.

Leo, R. A. (2008). Police interrogation and American justice. Cambridge, Mass: Harvard University Press.

Ma, Y. (2000). European Court of Human Rights and the Protection of the Rights of Prisoners and Criminal Defendants under the European Convention on Human Rights. International criminal justice review, 10, 54-80.

Ma, Y. (2007). A Comparative View of the Law of Interrogation. International Criminal Justice Review, 17 (1), 5-26.

McConville, M., Sanders, A. \& Leng, R. (1991). The case for the prosecution. London : Routledge.

Merrills, J. G. (1988). The development of international law by the European Court of Human Rights. Melland Schill monographs in international law. Manchester, UK: Manchester University Press.

O'Reilly, G. W. (1997). Comment on Ingraham's "Moral Duty" to Talk and the Right to Silence. Journal of Criminal Law and Criminology, 87 (2), 521-543.

Redmayne, M. (2007). Rethinking the Privilege Against Self-Incrimination. Oxford Journal of Legal Studies, 27 (2), 209-232.

Roth, K. (2008). Why the Current Approach to Fighting Terrorism Is Making Us Less Safe. Creighton Law Review, 41(4), 579-594.

Sanders, A., Young, R., \& Burton, M. (2010). Criminal justice $4^{\text {th }}$ edition. London: Oxford University Press.

Sanders, A. \& Young, R. (2007). From Suspect to Trial. In Maguire, M., Morgan, R., \& Reiner, R. (Eds.), The Oxford Handbook of Criminology (pp. 953-989). Oxford: Oxford University Press. 
Seidman, L. M. (1992). Brown and Miranda. California Law Review, 85(137), 673753.

Seidmann, D. J., \& Stein, A. (2000). The Right to Silence Helps the Innocent: A Game-Theoretic Analysis of the Fifth Amendment Privilege. Harvard Law Review, 114 (2), 431-510.

Spronken, T. Vermeulen, G., De Vocht, D., Van Puyenbroeck, L. (2009). EU procedural rights in criminal proceedings. Antwerp: Maklu.

Summers, S. J. (2007). Fair trials: The European criminal procedural tradition and the European Court of Human Rights. Oxford: Hart.

Toney, R. J. (2001). Disclosure of evidence and legal assistance at custodial interrogation: What does the European Convention on Human Rights require? International Journal of Evidence and Proof, 5, 39-60.

Van Kessel, G. (1998). European Perspectives on the Accused as a Source of Testimonial Evidence. Western Virginia Law Review, 100, 799-845.

Van Kessel, G. (2002). European Trends Towards Adversary Styles in Procedure and Evidence. In Feeley, M. \& Miyazawa, S. (Eds.), The Japanese Adversary System in Context: Controversies and Comparisons (pp. 225-262). Basingstoke: MacMillan.

Williams, J. W. (2000). Interrogating justice: A critical analysis of the police interrogation and its role in the criminal justice process. Canadian Journal of Criminology, 42, 209-240.

Zander, M. (1990). The Police and Criminal Evidence Act 1984. London: Sweet \& Maxwell Police Review Pub. Co. 